CASE SERIES AND REPORTS

\title{
Eagle's Syndrome, from clinical presentation to diagnosis and surgical treatment: a case report
}

\author{
Sindrome di Eagle: aspetti clinici, diagnostici e trattamento chirurgico

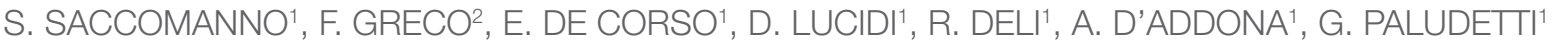 \\ ${ }^{1}$ Department of Head and Neck Surgery, "A. Gemelli" Hospital Foundation, Catholic University, Rome, Italy; \\ ${ }^{2}$ Department of Radiology, Nuovo San Giovanni Battista Hospital, Foligno, Italy
}

\section{SUMMARY}

Eagle's syndrome is a condition associated with the elongation of the styloid process or calcification of the stylohyoid ligament, clinically characterised by throat and neck pain, radiating into the ear. In this report, we describe the case of a 60-year-old woman who presented with a severe unilateral trigeminal and glossopharyngeal neuralgia. The patient was subjected to conservative therapy for four months and did not report improvement of the symptoms. After several consultations with different physicians, a diagnosis was accomplished by radiological investigation (multidetector computer tomography with multi-planar reconstructions and 3D volumetric reconstructions). Surgical styloidectomy was performed, with subsequent sudden remission of symptoms. Eagle's syndrome represents a commonly unrecognised nosological entity, clinically characterised by non-specific cranio-facial pain. Differential diagnosis includes glossopharyngeal and trigeminal neuralgia, temporal arteritis, migraine, myofascial pain dysfunction and cervical arthritis. Eagle's syndrome should always be suspected, mostly in adult women when the pain is unilateral and not responsive to painkillers.

KEY WORDS: Eagle's syndrome • Elongation of the stylohyoid process • Oropharyngeal pain • Glossopharyngeal neuralgia

\section{RIASSUNTO}

La sindrome di Eagle è caratterizzata dall'allungamento del processo stilo-ioideo elo dalla progressiva calcificazione del legamento stiloioideo. Il reperto è molto diffuso nella popolazione generale ma tale sindrome appare sintomatica solo in una piccola percentuale di casi. I sintomi sono rappresentati da: dolore ricorrente di tipo "trafittivo" riferito alla gola, regione antero-laterale del collo e orecchio, disfagia e sensazione di corpo estraneo in faringe. Riportiamo il caso clinico di una donna di 60 anni giunta alla nostra attenzione per dolore monolaterale sinistro, comparso da circa un mese, di tipo nevralgico, irradiato inizialmente solo lungo la branca mandibolare del nervo trigemino (nevralgia trigeminale) e successivamente alla regione laterocervicale omolaterale (nevralgia glossofaringea). La paziente era stata precedentemente valutata da numerosi specialisti e sottoposta per 4 mesi a terapia conservativa senza beneficio. La diagnosi è stata raggiunta mediante esami radiologici (Tomografia Computerizzata Multidetettore con ricostruzioni multiplanari e volumetriche 3D). È stata eseguita una stiloidectomia per via trans-cervicale, con successiva remissione dei sintomi. La sindrome di Eagle rappresenta un'entità nosologica comunemente misconosciuta, caratterizzata clinicamente da dolore cranio-facciale aspecifico. La diagnosi differenziale include la nevralgia del trigemino e glossofaringeo, l'arterite temporale, l'emicrania, il dolore miofasciale e l'artrosi cervicale. La sindrome di Eagle dovrebbe essere sempre sospettata, soprattutto nelle pazienti donne adulte e quando il dolore è unilaterale e non risponde agli antidolorifici.

PAROLE CHIAVE: Sindrome di Eagle $\bullet$ Processo stiloideo allungato $\bullet$ Dolore orofaringeo $\bullet$ Nevralgia del glossofaringeo

Acta Otorhinolaryngol Ital 2018;38:166-169

\section{Introduction}

Eagle's syndrome, defined by Eagle in 1949, is characterised by morphological abnormality/ossification of the styloid process ${ }^{1}$. The average length of the styloid process is $20-30$ $\mathrm{mm}$ in the adult Caucasians and 15.4-18.8 $\mathrm{mm}$ in the Asian population. An elongated styloid process is defined by being at least $30 \mathrm{~mm}$ long ${ }^{23}$. The clinical picture is composed of recurrent throat and neck pain, radiating into the ear and dysphagia. Symptoms can be bilateral or, more frequently, unilateral. The incidence is 4-8 per 10,000 people ${ }^{14}$.
The aetiology is not well defined and a number of theories have been suggested, such as congenital elongation due to the persistence of an embryonic cartilaginous outgrowth, calcification of the stylohyoid ligament and formation of bone tissue at the insertion of the ligament. This clinical picture might also be seen in patients after tonsillectomy ${ }^{5}$. We describe the case of a 60 -year-old woman who presented with left neuralgic pain, lasting for about a month, localised in the throat and neck and radiating into the ear. 


\section{Case report}

A 60-year-old woman presented with left neuralgic pain, lasting about a month, radiating at the first to the mandibular branch of the trigeminal nerve (trigeminal neuralgia) and later to the ipsilateral throat, tonsil, back of the tongue and ear (glossopharyngeal neuralgia).

An initial dental evaluation only showed a cavity on 38 so the dentist decided to extract the decayed tooth. However, despite the extraction, the pain still persisted and she decided to consult a gnathologist who prescribed painkillers. The patient was subjected for four months to conservative therapy consisting of $8 \%$ lidocaine spray on the oropharyngeal region corresponding to the tonsillar branches of the glossopharyngeal nerve, corticosteroids and NSAIDs per os. The patient, however, did not report improvement of symptoms, which worsened over time.

The patient described the pain as "stabbing" and not responding to painkillers. The sharp pain had the frequency of 10-20 episodes per hour and was less intense only in bed. It was exacerbated by yawning and crying. It was directed from the left side of the face towards the nose and throat, leaving a burning sensation, even after resolution. After several consultations with different physicians (physiotherapist, osteopath, neurologist, otolaryngologist), the patient was prescribed a more accurate radiologic investigation.

A panoramic X-Ray excluded osteo-dental alterations, and through $\mathrm{CT}$ scan expansive and osteolytic changes of the skull base were ruled out. Detailed MRI study of trigeminal ganglion was accomplished and no abnormalities were found. All these exams showed no pathological alterations on the oral cavity, oro-hypopharynx, larynx, soft tissues of the neck and temporal bones. However, radiologic attention was focused on the left stylo-mastoid process.

Multidetector computer tomography (MDTC) with multiplanar reconstructions (MPR) and 3D volumetric reconstructions (3D-VR) (Fig. 1) documented asymmetry of the stylo-hyoid process length, which was $27 \mathrm{~mm}$ from the right side and $30 \mathrm{~mm}$ from the left side. MDTC study of the bone allowed observing the extended length of the left stylohyoid process compared to the contralateral side (Fig. 2), allowing formulation of a hypothesis of Eagle's syndrome. Figure 3 shows shows the pre-operative comparison between sagittal views obtained by MDTC with 3D-VR and 2D-MPR.

As the symptoms intensified, the patient was urgently subjected to surgery: surgical resection of the left stylomastoid process, via a transcervical approach and under general anaesthesia was performed. Figures 4 and 5 show post-operative MDTC with 3D-VR and 2D-MPR, demonstrating a surgically amputated left styloid process.

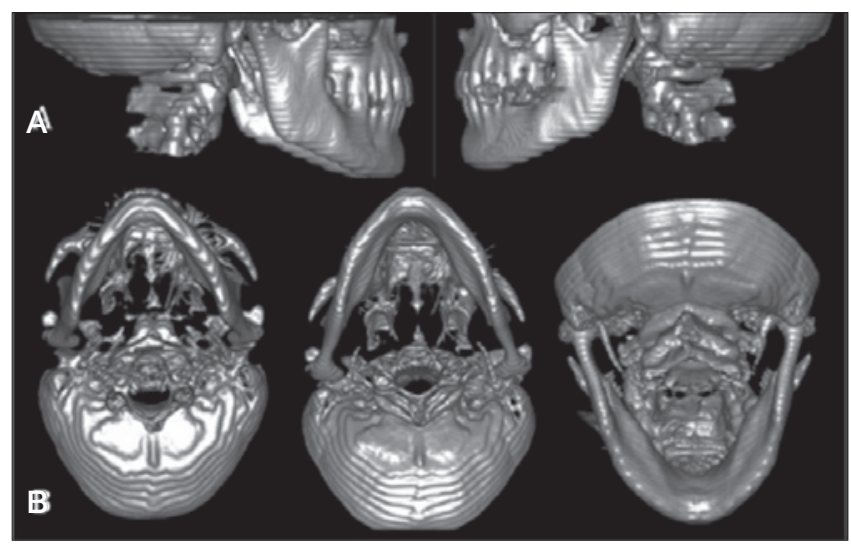

Fig. 1. Pre-operative 64-channel MDCT with multi-planar reconstructions (MPR) and 3D volumetric reconstructions (3D-VR) allowing to enhance the stylomastoid processes in the lateral (A) and craniocaudal (B) view.

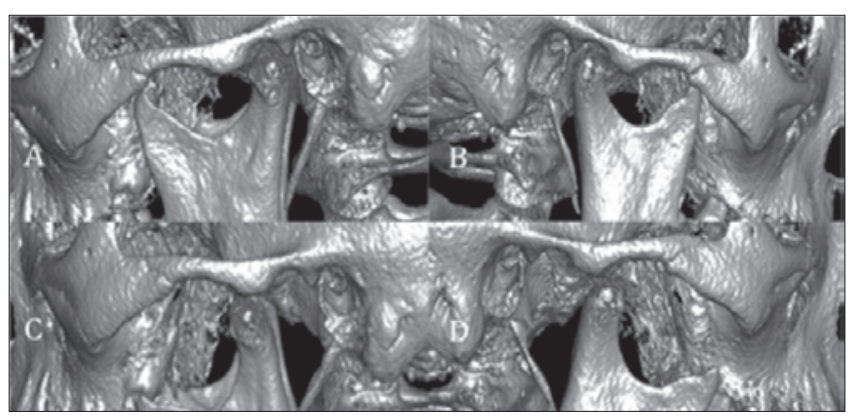

Fig. 2. pre-operative 64-channel MDCT with multi-planar reconstructions (MPR) and 3D volumetric reconstructions (3D-VR). Left- (A) and right-sided view (B) of the temporomandibular joint (closed mouth). Left- (C) and rightsided view (D) of the temporomandibular joint (open mouth).

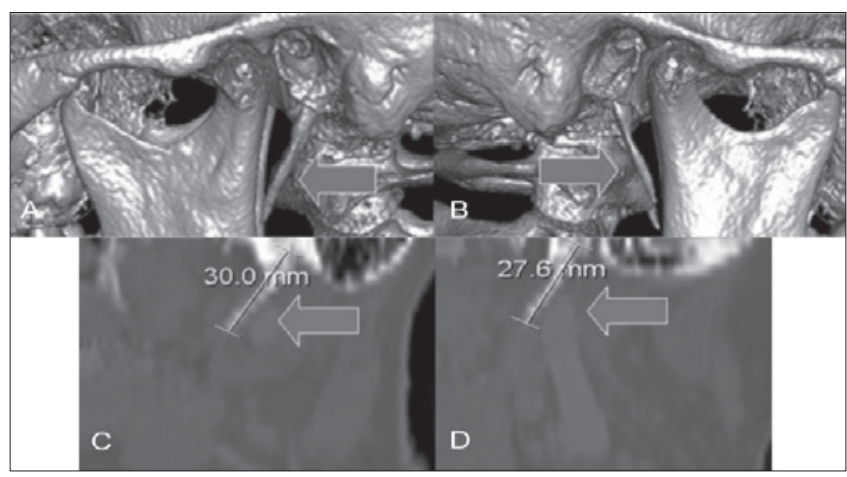

Fig. 3. Pre-operative comparison between MDCT with 3D VR sagittal views (A: left; B: right) and 2D MPR sagittal views (C: left; D: right).

After surgery the patient did not complain of any of the previously described symptoms, she did not need antiinflammatory drugs and regained a normal quality of life. 


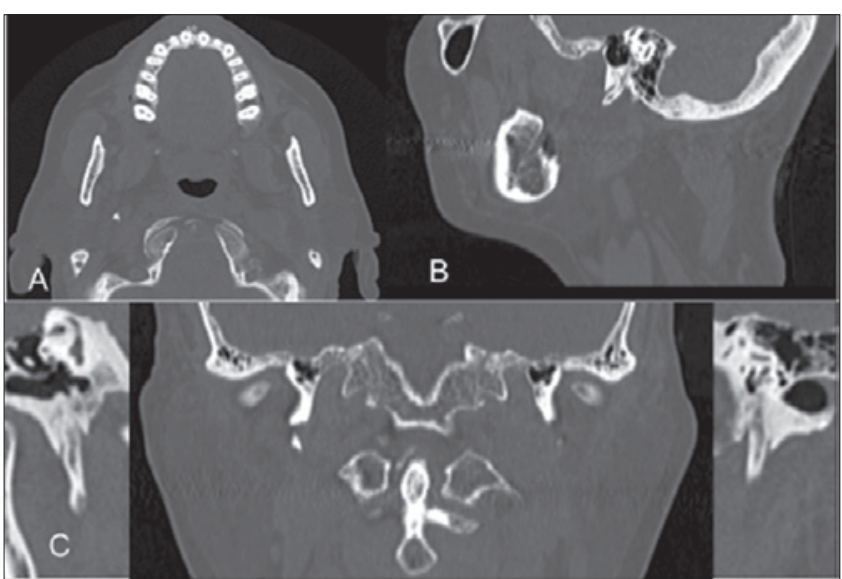

Fig. 4. Post-operative MDCT; A) axial view; B) sagittal view; C) coronal view showing comparison between normal right styloid process and surgically amputated left styloid process.

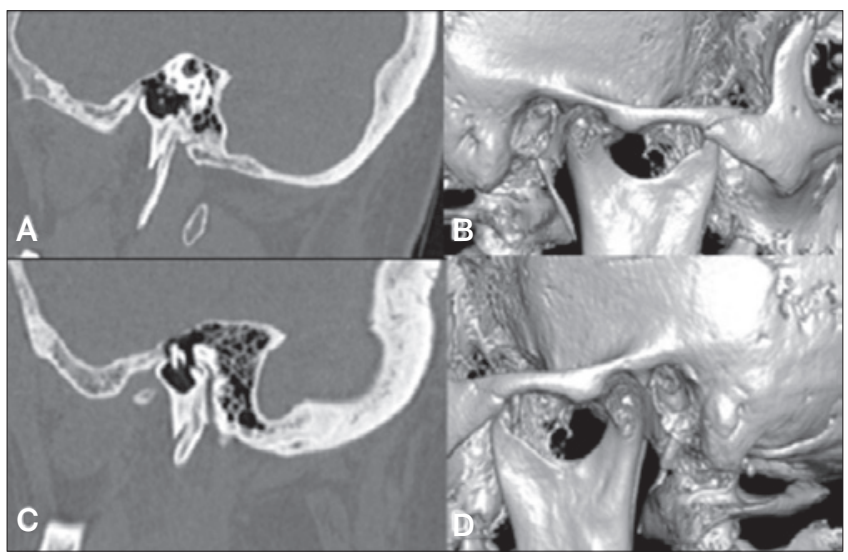

Fig. 5. Post-operative comparison between MDCT with 2D MPR sagittal views (A: right; C: left) and 3D VR sagittal views (B: right; D: left).

\section{Discussion}

Eagle's syndrome is related to the presence of an abnormally elongated styloid process with/without aberrant direction and/or ossificated styloid ligament. Cranio-facial pain resembles glossopharyngeal neuralgia and it is secondary to the irritation of the surrounding neurovascular and muscular anatomical structures (carotid artery, cranial nerves and muscles). It has been hypothesised that the pain deriving from the elongated styloid process may be due to compression of the glossopharyngeal nerve as it passes over the superior constrictor muscle. Rare cases of internal carotid artery compression/kinking have been described ${ }^{5}$. The styloid process may also compress the sympathetic nerve fibres, causing Horner syndrome ${ }^{6}$. The differential diagnosis should include glossopharyngeal and trigeminal neuralgia, temporal arteritis, migraine, cluster headache, myofascial pain dysfunction syndrome, pain related to un-erupted third molars, cervical arthritis, tumours and ill-fitting or missing dentures ${ }^{78}$.

The condition is more common in women and in patients older than 50 years. Mixed, non-specific symptoms, the absence of a clear aetiological link and the scant knowledge about this clinical entity often delay diagnosis, as described by our experience. Physical examination and clinical history are useful diagnostic tools. An elongated styloid process may be palpated during intraoral examination and may provoke the pain. Correct indication to radiological investigation, dedicated technology and experience are needed in order to reach a diagnosis. Although plain skull radiographs might be sufficient to reveal the anatomical abnormality, CT of the head/neck and especially 3D-CT scan is considered as the gold standard for visualisation of the anatomically complex styloid process, as it avoids the problems of obscured overlapping anatomy. Moreover, it underlines the styloid process angulation, which is crucial for the surrounding anatomical relationships. Some controversy exists in the literature as to how many patients with an elongated styloid apophysis, at radiologic examination, do not exhibit any clinical symptoms ${ }^{9}$. However, the surgical approach in patients with a diagnosis of Eagle's syndrome is quite conclusive: surgical styloidectomy has, in fact, a cure rate of $80 \%$.

\section{Conclusions}

Eagle's syndrome should always be suspected when idiopathic unilateral pain occurs, especially in adult women and when the pain is not responsive to painkillers. In addition, the exacerbation of the pain by swallowing, yawning and crying, as in our patient, should help in diagnosis. Patients often seek assistance by many clinicians, which is related to the non-specificity of symptoms, with poor success. Multidisciplinary approach, early indication to radiological investigation, especially MDCT of the styloid process is advisable in such cases. The elongation of the styloid process is a relatively common condition, although not all the affected patients complain of symptoms. When occurring, the diagnostic workup may be critical, since throat and neck pain, mild dysphagia and foreign body sensation in the pharynx are misleading symptoms. Otolaryngologists, neurologists and dental surgeons should be aware of the existence and incidence of this clinical entity, which is associated with a critical decay in the quality of life.

\section{References}

Kawasaki M, Hatashima S, Matsuda T. Non-surgical therapy for bilateral glossopharyngeal neuralgia caused by Eagle's 
syndrome, diagnosed by three-dimensional computed tomography: a case report. J Anesth 2012;26:918-21.

2 Ceylan A, Köybaşioğlu A, Çelenk F et al. Surgical treatment of elongated styloid process: experience of 61 cases. Skull Base 2008;18:289-95.

3 Raina D, Gothi R, Rajan S. Eagle syndrome. Indian J Radiol Imaging 2009;19:107-8.

4 Baddour HM, Mc Anear Jt, Tilson AB. Eagles syndrome report of case. J Oral Surg 1978; 36:486.

5 Radak D, Tanaskovic S, Kecmanovic V, et al. Bilateral Eagle syndrome with associated internal carotid artery kinking and significant stenosis. Ann Vasc Surg 2016;34:15-8.

6 Chang CA, Lin T, Fung K, et al. Isolated Horner Syndrome from an elongated styloid process (Eagle syndrome). J Neuroophthalmol 2015;35:387-9.

7 Santos Tde S, Vajgel A, Camargo IB, et al. Clinical-radiographic analysis of Eagle syndrome. J Craniofac Surg 2014;25:1578-9.

8 Costantinides F, Vidoni G, Tonni I, et al. Orofacial pain induced by Eagle syndrome in an elderly patient with temporomandibular disorders - a case report. Gerodontology 2016;33:428-31.

9 Kent DT, Rath TJ, Snyderman C. Conventional and 3-dimensional computerized tomography in Eagle's syndrome, glossopharyngeal neuralgia, and asymptomatic controls. Otolaryngol Head Neck Surg 2015;153:41-7.

Received: October 25, 2016 - Accepted: October 27, 2016

Address for correspondence: Sabina Saccomanno, Department of Head and Neck Surgery, Catholic University, “A. Gemelli” Hospital Foundation, 1.go F. Vito 1, 00168 Rome, Italy. E-mail: sabinasaccomanno@hotmail.it 